(RESEARCH ARTICLE)

\title{
Quantitative evaluation of hydrogen cyanide content, chemical and functional properties of gari from Akwanga, Nasarawa State, Nigeria
}

\author{
Kreni Comfort Gudi ${ }^{1}$, Akande Samuel Adesayo ${ }^{2,}{ }^{*}$, Ayanda Ifedapo Solomon ${ }^{2}$ and Ibrahim Adeola Saheed 2 \\ ${ }^{1}$ Department of Home Economics, College of Education (COE), P. M. B. 05, Along Jos Road, Akwanga, Nasarawa State, \\ Nigeria. \\ ${ }^{2}$ Nigerian Stored Products Research Institute (NSPRI) Headquarters, Km 3, Asa-Dam Road, P. M. B. 1489, Ilorin, Kwara \\ State, Nigeria.
}

Publication history: Received on 31 October 2019; revised on 19 November 2019; accepted on 21 November 2019

Article DOI: https://doi.org/10.30574/wjarr.2019.4.1.0081

\begin{abstract}
Ingestion of cyanohydrins has been linked to acute and chronic toxicities even death on several occasions in Nigeria. The need for periodic evaluation of cassava based food products to ensure compliance to standard specifications is therefore imperative. This study was conducted to investigate the concentration of hydrogen cyanide and other quality parameters of gari samples collected from Akwanga main market in the month of July, 2019. A total of 21 samples of gari (16 white and 5 yellow varieties) were collected using systematic random sampling techniques. Hydrogen cyanide, proximate compositions, physicochemical and functional properties were carried out following standard procedures. Results showed that white and yellow gari contained hydrogen cyanide in the range of 3.68-19.37 mg/kg and $13.32-$ $16.17 \mathrm{mg} / \mathrm{kg}$ respectively. High moisture (11.38-16.74\%) and crude fibre (1.51-3.44\%) contents were recovered in some white gari and all the yellow gari samples. The results obtained for pH (4.44-5.95) and titratable acidity (0.11$0.67 \%$ ) indicated low acid concentrations in both gari varieties. The bulk density, water absorption capacity, swelling index and least gelation capacity varied significantly in white and yellow gari samples as from $0.12-0.87 \mathrm{~g} / \mathrm{mL}, 4.06-$ $5.40 \mathrm{~mL} / \mathrm{g}, 0.47-4.40$ and 3.00-6.70\% respectively. The concentrations of hydrogen cyanide in all the samples were higher than maximum value $(2.0 \mathrm{mg} / \mathrm{kg}$ ) considered as National Standard Specifications for gari coupled with high moisture contents above the safe level which might predispose them to mould growth that could render them unsafe for human consumption.
\end{abstract}

Keywords: Cassava; Value-Chain; Postharvest; Processing; Cyanogenic Glycosides

\section{Introduction}

Cassava (Manihot esculenta Crantz), also known as manioc or yuca in some parts of the world, has been a major food crop in Nigeria for more than a century and It's considered an important source of energy in the country's diets [1-3] and many other parts of the world [4]. For instance, the roots of cassava are processed or eaten by 500 million people a day in Africa, where it is a staple for $40 \%$ of the population [5]. Nigeria is the largest producer of cassava in the world with about 38 million metric tons per annum; and this figure is expected to double by the end of year 2020 [6]. In Nigeria, cassava roots has been processed into a number of invaluable products including 'gari', bread, 'fufu', tapioca, cassava chips, high quality cassava flour (HQCF), 'abacha', starch and many more, of which some are highly priced in large cities due to rapid urbanization throughout Sub-Saharan Africa [7-8]. Gari, as one of different kinds of food products that can be obtained from fresh cassava roots is a very popular food in West Africa and it is fast becoming a marketable product $[1,8]$. It is a dry, crispy, creamy-white or yellow and granular in nature [8]. The processing involves; sorting/peeling the roots, washing, crushing/grating into cassava mash, fermenting the mash (48 hr), pressing, sifting/sieved into small pieces (known as grits), further the grits are then garified/roasted/fried/toasted to make the final crispy product called

\footnotetext{
${ }^{*}$ Corresponding author

E-mail address: desayoakande60@gmail.com
} 
gari $[1,5,7,8]$. Little palm oil (red oil) may be added during garifying. Hence, two types of gari exist namely; white and yellow types depending on the amount of red oil added during processing. In facts, addition of palm oil to gari during processing has been reported to protect attack by mould, increase the appeal and even the vitamin A content [9].

One of the limiting factors or constraints facing the processing and utilization of cassava into useful products is the concentrations of cyanogenic glycosides present in the roots. This substance gives rise to varying concentrations of hydrogen cyanide which is poisonous to human [8]. Different varieties of cassava contain different amounts of hydrogen cyanide. Roots that contain high amounts of cyanide normally taste bitter and should not be eaten raw, while the roots of 'sweet' varieties contain low levels of cyanide and can be eaten raw [8]. Proper processing converts fresh cassava roots into safer and more marketable products by; reducing cyanide levels in the processed products, prolonging shelf life, reducing post-harvest losses of fresh cassava roots, avoiding contamination of the products and the environment, increasing the nutritional value of cassava (e.g., by adding grain legumes during processing), increasing the market value of cassava and reducing transport costs [8]. In order to avoid the grave consequences of poor quality foods, Nigeria and many countries of the world have set different standards for different products including cassava products; for instance, the National Standards Specifications and Codex Alimentarious for gari were as presented (Table 1). Nevertheless, many research reports have shown that hydrogen cyanide concentrations of cassava products including gari in different parts of the country were above these standards [9-14].

Table 1: National Standard Specifications (Nigeria) and Codex Alimentarious for gari

\begin{tabular}{|l|l|l|}
\hline Parameters & Nigeria & Codex Alimentarious \\
\hline Ash (\%) & 2.75 & 2.75 \\
\hline Fibre (\%) & 2.00 & 2.00 \\
\hline Hydrogen cyanide (mg/kg) & 2.00 & 2.00 \\
\hline Moisture (\%) & 12.00 & 12.00 \\
\hline Total acidity (\%) & $0.60-1.00$ & $0.60-1.00$ \\
\hline & Source: Oti et al. [7]. & \\
\hline
\end{tabular}

Therefore, the objective of this study was to evaluate the cyanide contents and other quality parameters of gari obtained from Akwanga Local Government Area of Nasarawa State, Nigeria with a view to compare them with standard specifications. The results of this research work may be useful in formulating a policy framework to guide all stakeholders who are involved in the cassava value-chain especially the government in alleviating or mitigating the grave consequences of unwholesome products being displayed in Nigerian markets.

\section{Material and methods}

\subsection{Reagents}

All reagents used were of analytical grade, they were obtained from accredited distributors in Nigeria. These include; picric acid (CDH: Central Drug House, India), potassium cyanide (BDH, England), sodium trioxocarbonate (IV) (BDH, England), sodium hydroxide pellets (Loba Chemie PVT, India), hydrochloric acid (BDH, England) and sulphuric acid (BDH, England).

\subsection{Survey and sampling area}

The survey was conducted in Akwanga, Akwanga Local Government Area of Nasarawa State, Nigeria in the month of July, 2019. Akwanga is located on latitude 8.9067 degree north of equator and longitude 8.4075 degree east of Greenwich meridian, about $110 \mathrm{~km}$ east of Abuja, Nigeria (Plate 1). A total of 21 traders were selected using systematic random sampling techniques and their gari samples containing white and yellow varieties were collected and kept in air-tight containers under ambient conditions $\left(27^{\circ} \mathrm{C}, 70 \% \mathrm{RH}\right)$ in the laboratory until analyses. Table 2 contains the outline of white and yellow gari samples collected with their respective codes. 


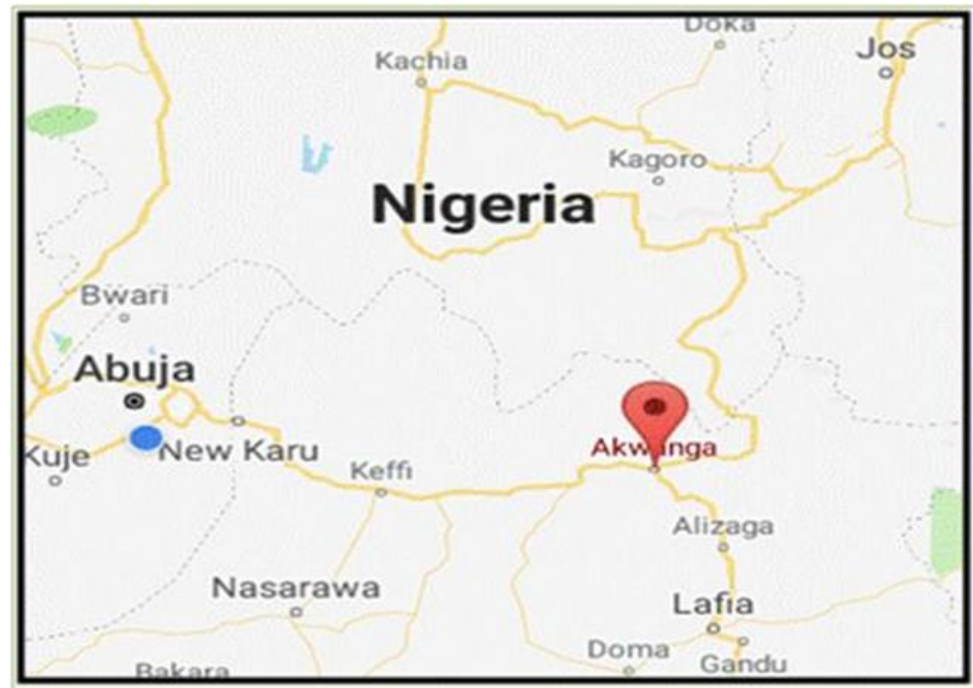

Figure 1 Map showing the sampling area (Akwanga). Source: Google Map Data (C2019

Table 2 Samples of white and yellow gari with their respective codes

\begin{tabular}{|l|l|l|l|}
\hline White gari & Code & Yellow gari & Code \\
\hline 1 & A & 1 & A \\
\hline 2 & B & 2 & B \\
\hline 3 & C & 3 & C \\
\hline 4 & D & 4 & D \\
\hline 5 & E & 5 & E \\
\hline 6 & F & & \\
\hline 7 & G & & \\
\hline 8 & H & & \\
\hline 9 & I & & \\
\hline 10 & J & & \\
\hline 11 & K & & \\
\hline 12 & L & & \\
\hline 13 & M & & \\
\hline 14 & N & & \\
\hline 15 & O & P & \\
\hline 16 & & & \\
\hline
\end{tabular}

\subsection{Analysis of cyanide contents}

The alkaline picrate method as described by [15] was partially modified and used in the determination of hydrogen cyanide contents as follows; $5 \mathrm{~g}$ finely grounded gari sample was dissolved in $50 \mathrm{~mL}$ distilled water in a corked conical flasks and left to stay overnight for proper extraction of the hydrogen cyanide.

The extract was filtered through Whatman number 1 filter paper. To $1 \mathrm{~mL}$ of the extract was added $4 \mathrm{~mL}$ alkaline picrate solution and incubated in the water bath at $37^{\circ} \mathrm{C}$ for 15 minutes for colour development. The absorbance was read with UV-Vis Spectrophotometer (UV1902PC: Searchtech Instruments, England) at $490 \mathrm{~nm}$ against the reagent blank containing $1 \mathrm{~mL}$ of distilled water and $4 \mathrm{~mL}$ of alkaline picrate solution prepared at the same time. Cyanide concentrations of the gari samples were extrapolated from the cyanide standard curve prepared by using pure potassium cyanide (BDH, England). 


\subsection{Proximate analysis}

The proximate analysis was carried out on the gari samples following the method of [16]. The moisture was determined by hot air oven method at $105^{\circ} \mathrm{C}$ for $5 \mathrm{hr}$. The micro kjeldahl method was used for the determination of protein content. The fat content was determined by extracting $5 \mathrm{~g}$ of sample with petroleum ether (boiling point of 40 to $60^{\circ} \mathrm{C}$ ) using soxhlet solvent extraction method. Ash was determined by weighing $5 \mathrm{~g}$ of charred sample into a tarred porcelain crucible which was incinerated at $600^{\circ} \mathrm{C}$ for $6 \mathrm{hr}$ in an ash muffle furnace until ash was obtained. The crude fiber was determined by exhaustive extraction of soluble substances in sample using $1.25 \% \mathrm{H}_{2} \mathrm{SO}_{4}$ acid and $1.25 \% \mathrm{NaOH}$ solution after which the residue was ashed and the loss in weight was recorded as crude fiber. The carbohydrates content was determined by difference: $100-(\%$ Moisture $+\%$ Ash $+\%$ Protein $+\%$ Fat $+\%$ Crude fiber $)$.

\subsection{Physicochemical analysis}

Total titratable acidity (TTA) and pH of gari samples were determined following the method of [17]. Briefly, $3 \mathrm{~g}$ each of gari samples was added with $27 \mathrm{~mL}$ of distilled water $(10 \% \mathrm{w} / \mathrm{v})$ and left to stand for $30 \mathrm{~min}$ before being filtered with Whatman No. 4 filter paper. The pH-meter (PHS-3C: Searchtech Instrument, England) was used and the readings were expressed as $\mathrm{pH}$. Thereafter 3 drops of phenolphthalein solution were added to the filtrate as indicator and then titrated against a standard base $(0.1 \mathrm{~N} \mathrm{NaOH})$ to a $\mathrm{pH}$ reading of 8.1 (rose pink colour). Total acidity was estimated according to the formula;

$$
\text { TotalAcidity }(\% w / w)=\frac{N \times V \times E q w t}{W \times 1000} \times 100
$$

where;

$\mathrm{N}=$ Normality of $\mathrm{NaOH}\left(\mathrm{MEqmL}^{-1}\right)$

$\mathrm{V}=$ Volume of $0.1 \mathrm{~N} \mathrm{NaOH}$ used

Eqwt=Equivalent weight of predominant acid in gari ( $\mathrm{mg} \mathrm{mEq}^{-1}$ lacetic acid)

W=Weight of sample

$1000=$ Factor relating $\mathrm{mg}$ to gram $\left(\mathrm{mg} \mathrm{g}^{-1}\right)$.

\subsection{Determination of functional properties}

Bulk density (BD), Water absorption capacity (WAC) and least gelation capacity (LGC) of gari samples were determined by following the methods described by [15]. The Swelling index (SI) was determined following the method described by [18].

\subsubsection{Bulk density (BD)}

A known weight of the sample was poured into a clean measuring cylinder and the bottom being tapped continuously on the laboratory bench till no further reduction in volume was observed. The volume being read directly on the measuring cylinder and the value was expressed as gram per unit volume $(\mathrm{g} / \mathrm{mL})$ according to the equation below;

$$
\text { Bulk Density }(g \text { per } m L)=\frac{\text { Weight of sample }}{\text { Volume of sample }}
$$

\subsubsection{Water absorption capacity (WAC)}

To $1 \mathrm{~g}$ of each sample was mixed thoroughly $10 \mathrm{~mL}$ of distilled water in a conical graduated centrifuge tube for 30 seconds. The setup was allowed to stand for $30 \mathrm{~min}$ at room temperature $\left(27^{\circ} \mathrm{C}\right)$ and then centrifuged at $4800 \mathrm{x} g$ for 30 minutes using a centrifuge (K2202: Centurion Scientific, England). The volume of the free water above was read directly from the graduated centrifuge tube and expressed as $\mathrm{mL}$ of water absorbed per unit gram of sample (mL/g) according to equation below;

$$
W A C(m L \text { per } g)=\frac{\text { Initial volume of water }- \text { volume of free water }}{\text { Weight of sample }}
$$




\subsubsection{Least gelation capacity (LGC)}

Varying amounts from $2-40 \%(\mathrm{w} / \mathrm{v})$ of sample were prepared in $5 \mathrm{~mL}$ of distilled water in glass test tubes. The sample test tubes were then heated in a boiling water bath for $1 \mathrm{hr}$ followed by rapid cooling under running tap water. The test tubes were further cooled at $4{ }^{\circ} \mathrm{C}$ and the gelation capacity was taken as the least gelation concentration determined as the concentration when the sample from the inverted test tube did not fall or slip down.

\subsubsection{Swelling index (SI)}

To $1 \mathrm{~g}$ of sample was added $5 \mathrm{~mL}$ of distilled water in a measuring cylinder $(10 \mathrm{~mL})$, the volume occupied was recorded before adding the water and left to stand for one hour and the new volume was noted. Swelling index was calculated as follows;

$$
\text { SwellingIndex }=\frac{\text { Volume occupied by sample before swelling }}{\text { Volume occupied after swelling }}
$$

\subsection{Data analysis}

Results were expressed as mean \pm SD of replicate determinations $(n=3)$. All data generated were subjected to statistical test by one-way analysis of variance (ANOVA) using the SPSS statistical software package version 20.0.0 (IBM SPSS Statistics, IBM Corporation 2011). The difference between means was determined by using New Duncan Multiple Range F-Tests (DMRT) as described by [19]. Significance was accepted at 5\% probability level $(\mathrm{p}=0.05)$.

\section{Results and discussion}

\subsection{Hydrogen cyanide contents of white and yellow gari samples from Akwanga, Nasarawa State, Nigeria}

The hydrogen cyanide contents of white gari samples collected from Akwanga, Nasarawa State were as shown (Figure 2 left). Hydrogen cyanide content of white gari varied significantly from $3.68 \mathrm{mg} / \mathrm{kg}$ (sample F) to $19.37 \mathrm{mg} / \mathrm{kg}$ (sample $\mathrm{J}$ ). A similarity was recorded in sample pairs B and $\mathrm{H}$ with $\mathrm{M}$ and $\mathrm{P}$. This observation showed that the different gari samples might have probably come from the same source. Similarly, the hydrogen cyanide contents of yellow gari collected from Akwanga, Nasarawa State were shown in Figure 2 (right). The results indicated that hydrogen cyanide content of yellow gari varied significantly from $13.32 \mathrm{mg} / \mathrm{kg}$ (sample B) to $16.17 \mathrm{mg} / \mathrm{kg}$ (sample E). The results further revealed that $100 \%$ of the total white and yellow gari samples collected had hydrogen cyanide contents that were above the maximum allowable level $(2.0 \mathrm{mg} / \mathrm{kg})$.

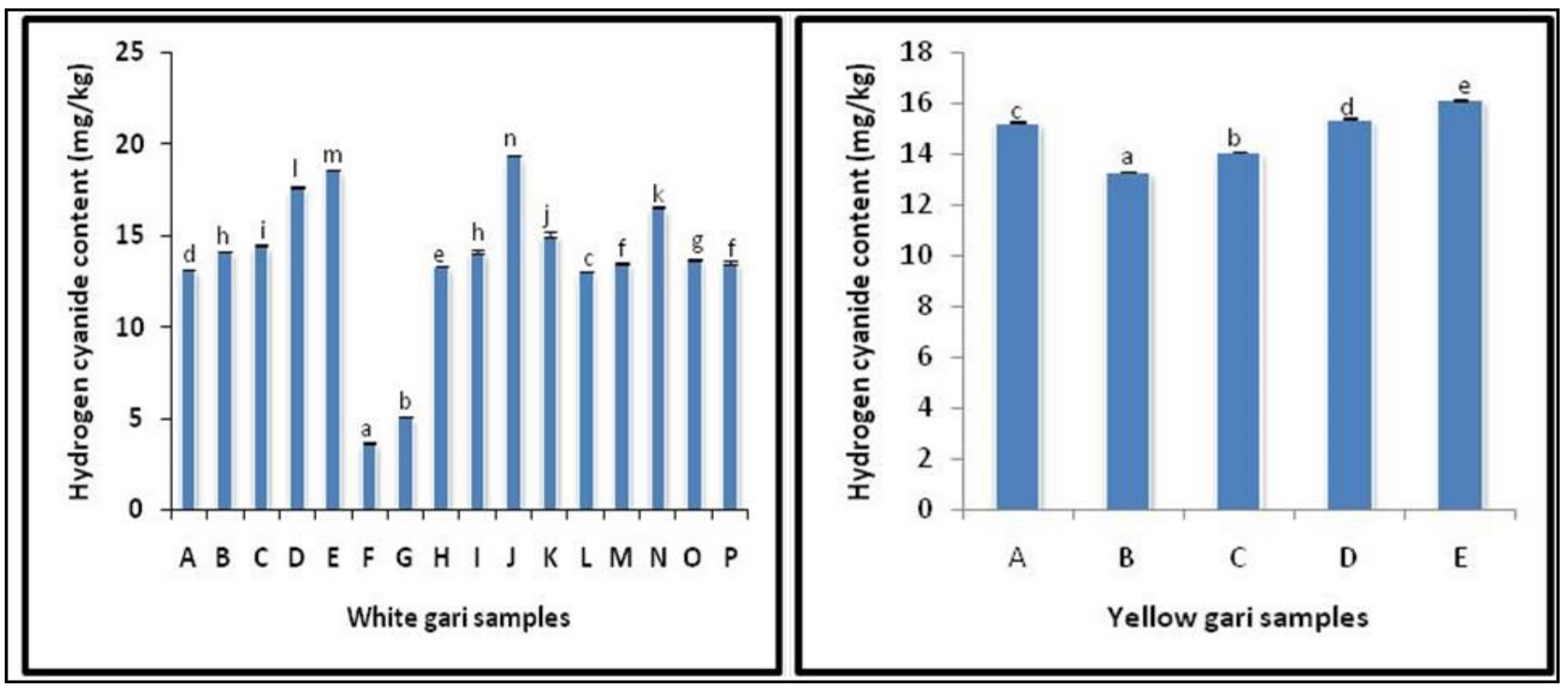

Figure 2 Hydrogen cyanide contents of white (left) and yellow (right) gari samples collected from Akwanga, Nasarawa State. Each column bar represents mean of three determinations $(n=3)$ while the error bar represents standard deviation (SD) of the mean. Column bars with unshared alphabets (lower case letters) on top are significantly different at $\mathrm{P}_{\text {value }}=0.05(\mathrm{p}=0.05)$. Letters (upper case) are codes representing white and yellow gari samples respectively. 
The results of hydrogen cyanide contents of white and yellow gari in this study corroborate the available literature reports; gari taken from Okada, Edo State, Nigeria contained $5 \mathrm{mg} / \mathrm{kg}$ [13], another sample taken from Karu, Nasarawa State, Nigeria contained $8.54 \mathrm{mg} / \mathrm{kg}$ [12]. More resent report showed as high as 16 and $20 \mathrm{mg} / \mathrm{kg}$ hydrogen cyanide contents of white and yellow gari respectively for samples from Ilorin, Kwara State, Nigeria [14].

\subsection{Proximate composition of white and yellow gari collected from Akwanga, Nasarawa State, Nigeria}

The proximate composition of white gari samples collected from Akwanga, Nasarawa State, Nigeria was as presented (Table 3). The results indicated that moisture content of white gari samples varied significantly from $11.38 \%$ (sample $\mathrm{O}$ and $\mathrm{N}$ ) to $16.74 \%$ (sample $\mathrm{C}$ ). However, similarities exist within the moisture contents of the following four groups of white gari in the order listed below; samples $\mathrm{M}, \mathrm{N}$ and $\mathrm{O}$, samples B, D, F, H, I, J, L and M, samples A, K and P and lastly samples $\mathrm{E}$ and $\mathrm{G}$. The data presented in Table 4 showed that the moisture contents of yellow gari samples varied significantly from $14.21 \%$ (sample D) to $16.05 \%$ (sample E). However, no significant difference ( $p=0.05$ ) was recorded between the moisture content of sample $\mathrm{D}$ and $\mathrm{A}$. The moisture content of gari is an important quality index that can be used to predict its shelf life. High moisture content might encourage mould growth during storage of gari [1]. According to them, the safe moisture content for gari was in the range between 12.7 to $13.6 \%$, but the Nigerian National Standard Specifications and Codex Alimentarious Standards gave 12.0\% maximum for safe level [7]. The safe moisture level for a particular food is the moisture at which the food can maintain equilibrium with $70 \%$ atmospheric relative humidity around the food [1]. Going by the National Standard Specifications, the results in this study demonstrated that only $50 \%$ of the total white gari and none of yellow gari sample fell within acceptable limit (12.0\%). The moisture content reported in this study (11.38-16.74\% and 14.21-16.05\% for white and yellow gari respectively) was found to be lower than moisture contents (17.2\% and $17.8 \%$ respectively) reported for the same gari varieties from six markets in Ilorin city [1], but was slightly higher than values (7.72-11.40\% and 8.28-13.35\% respectively) as reported recently for the same city [20].

The ash contents of white gari samples varied significantly from $0.42 \%$ (sample G) to $2.17 \%$ (sample A) while that of yellow gari samples varied significantly from $0.71 \%$ (sample B) to $1.07 \%$ (sample A). However, a similarity exist between samples B (0.71\%) and C (0.75\%) as well as between samples A (1.07\%) and D (1.05\%) in their ash contents. Ash content is a measure of the amount of minerals in a food substance. The Nigerian National Standard Specifications for gari required that the maximum ash content of gari should not exceed $2.75 \%$ according to [7]. All the gari samples (white and yellow varieties) examined in this study fell below this threshold; hence, they might be regarded as being acceptable in terms of ash contents.

Table 3 Proximate composition of white gari obtained from Akwanga, Nasarawa State, Nigeria (wet basis)

\begin{tabular}{|c|c|c|c|c|c|c|}
\hline Sample & $\begin{array}{l}\text { Moisture } \\
(\%)\end{array}$ & $\begin{array}{l}\text { Ash } \\
(\%)\end{array}$ & $\begin{array}{l}\text { Crude } \\
\text { Protein (\%) }\end{array}$ & $\begin{array}{l}\text { Fat } \\
(\%)\end{array}$ & $\begin{array}{l}\text { Crude Fibre } \\
\text { (\%) }\end{array}$ & $\begin{array}{l}\text { Carbohydrates } \\
(\%)\end{array}$ \\
\hline A & $13.92^{\mathrm{e}} \pm 0.14$ & $2.17^{f} \pm 0.04$ & $0.84^{b} \pm 0.11$ & $0.53^{\mathrm{ab}} \pm 0.06$ & $2.67 \mathrm{fg} \pm 0.12$ & $78.54^{b} \pm 2.32$ \\
\hline B & $11.93^{\mathrm{bcd}} \pm 0.67$ & $1.36^{\mathrm{cd}} \pm 0.28$ & $1.01^{b c} \pm 0.00$ & $0.52^{\mathrm{ab}} \pm 0.08$ & $2.43^{\mathrm{e}} \pm 0.03$ & 83.09 ef \pm 0.35 \\
\hline $\mathrm{C}$ & $16.74^{\mathrm{h}} \pm 0.02$ & $2.13^{f} \pm 0.24$ & $1.37^{\mathrm{d}} \pm 0.00$ & $0.54^{\mathrm{ab}} \pm 0.05$ & $2.13^{d} \pm 0.02$ & $77.09^{a} \pm 0.19$ \\
\hline D & $11.93^{\mathrm{bcd}} \pm 0.07$ & $1.61^{\mathrm{de}} \pm 0.07$ & $1.57 \mathrm{de} \pm 0.10$ & $0.44^{\mathrm{ab}} \pm 0.00$ & $1.51^{\mathrm{a}} \pm 0.13$ & $82.93^{\mathrm{ef}} \pm 0.20$ \\
\hline E & $14.66^{g} \pm 0.05$ & $1.34^{\mathrm{cd}} \pm 0.20$ & $0.84^{b} \pm 0.00$ & $0.43^{\mathrm{ab}} \pm 0.03$ & $2.19^{\mathrm{d}} \pm 0.05$ & $80.51^{c} \pm 0.22$ \\
\hline $\mathrm{F}$ & $12.30^{\mathrm{d}} \pm 0.32$ & $0.97 b c \pm 0.51$ & $1.88^{f} \pm 0.11$ & $1.30^{c} \pm 0.39$ & $2.64 \mathrm{fg} \pm 0.08$ & $81.04^{c d} \pm 0.88$ \\
\hline G & $14.44^{\mathrm{fg}} \pm 0.41$ & $0.42^{\mathrm{a}} \pm 0.01$ & $1.04^{b c} \pm 0.05$ & $0.42^{\mathrm{ab}} \pm 0.01$ & $2.24^{\mathrm{d}} \pm 0.06$ & $81.38^{\mathrm{cd}} \pm 0.39$ \\
\hline $\mathrm{H}$ & $11.93^{\mathrm{bcd}} \pm 0.02$ & $1.03^{b c} \pm 0.02$ & $0.91^{b c} \pm 0.05$ & $0.49^{\mathrm{ab}} \pm 0.00$ & $1.53^{\mathrm{a}} \pm 0.05$ & $84.10^{f} \pm 0.15$ \\
\hline I & $11.79^{a b c} \pm 0.01$ & $1.49^{d} \pm 0.06$ & $0.57^{a} \pm 0.11$ & $0.50^{\mathrm{ab}} \pm 0.00$ & $2.19^{\mathrm{efg}} \pm 0.08$ & $83.57^{f} \pm 0.15$ \\
\hline $\mathrm{J}$ & $11.95^{\mathrm{bcd}} \pm 0.06$ & $1.61^{\mathrm{de}} \pm 0.07$ & $1.13^{c} \pm 0.01$ & $0.54^{\mathrm{ab}} \pm 0.04$ & $2.72^{\mathrm{g}} \pm 0.09$ & $82.07^{\mathrm{de}} \pm 0.21$ \\
\hline $\mathrm{K}$ & $14.06^{\mathrm{ef}} \pm 0.32$ & $1.45^{\mathrm{d}} \pm 0.17$ & $1.05^{b c} \pm 0.02$ & $2.46^{\mathrm{d}} \pm 0.50$ & $2.54^{\mathrm{ef}} \pm 0.19$ & $78.43^{b} \pm 0.70$ \\
\hline $\mathrm{L}$ & $12.22^{\mathrm{cd}} \pm 0.03$ & $1.53^{\mathrm{d}} \pm 0.19$ & $2.04^{\mathrm{fg}} \pm 0.13$ & $0.71^{b} \pm 0.00$ & $1.89^{c} \pm 0.06$ & $81.61^{c d} \pm 0.40$ \\
\hline M & $11.52^{\mathrm{ab}} \pm 0.15$ & $1.64^{\mathrm{de}} \pm 0.05$ & $4.46^{\mathrm{i}} \pm 0.42$ & $0.43^{\mathrm{ab}} \pm 0.01$ & $1.61^{\mathrm{ab}} \pm 0.11$ & $80.33^{c} \pm 0.38$ \\
\hline $\mathrm{N}$ & $11.40^{\mathrm{a}} \pm 0.35$ & $0.82^{\mathrm{b}} \pm 0.00$ & $2.16^{\mathrm{g}} \pm 0.02$ & $0.42^{\mathrm{ab}} \pm 0.01$ & $2.13^{d} \pm 0.05$ & $83.07^{\mathrm{ef}} \pm 0.36$ \\
\hline 0 & $11.38^{a} \pm 0.18$ & $1.46^{\mathrm{d}} \pm 0.14$ & $4.23^{h} \pm 0.09$ & $0.32^{\mathrm{a}} \pm 0.00$ & $1.49^{\mathrm{a}} \pm 0.08$ & $81.12^{\mathrm{cd}} \pm 0.47$ \\
\hline $\mathrm{P}$ & $13.73^{\mathrm{e}} \pm 0.00$ & $1.95^{\mathrm{ef}} \pm 0.44$ & $1.61^{\mathrm{e}} \pm 0.09$ & $0.31^{\mathrm{a}} \pm 0.01$ & $1.74^{b c} \pm 0.06$ & $80.69^{c} \pm 0.35$ \\
\hline Min. & 11.38 & 0.42 & 0.57 & 0.31 & 1.49 & 77.09 \\
\hline Max. & 16.74 & 2.17 & 4.46 & 2.46 & 2.72 & 84.10 \\
\hline
\end{tabular}

Results show mean \pm standard deviation of triplicate readings $(n=3)$. a, b, c, dMeans with the same alphabets within the same column are not significantly different from one another at $\mathrm{P}_{\text {value }}=0.05(\mathrm{p}=0.05)$. Letters $\mathrm{A}$ to $\mathrm{P}$ (upper case letters) represent different codes for white gari samples collected. 
Table 4 Proximate composition of yellow gari sample collected from Akwanga, Nasarawa State, Nigeria (wet basis)

\begin{tabular}{|l|l|l|l|l|l|l|}
\hline Sample & $\begin{array}{l}\text { Moisture } \\
\text { (\%) }\end{array}$ & $\begin{array}{l}\text { Ash } \\
\text { (\%) }\end{array}$ & $\begin{array}{l}\text { Crude } \\
\text { Protein (\%) }\end{array}$ & $\begin{array}{l}\text { Fat } \\
\text { (\%) }\end{array}$ & $\begin{array}{l}\text { Crude } \\
\text { Fibre (\%) }\end{array}$ & $\begin{array}{l}\text { Carbohydrates } \\
\text { (\%) }\end{array}$ \\
\hline A & $14.36^{\mathrm{a}} \pm 0.16$ & $1.07^{\mathrm{c}} \pm 0.02$ & $1.42^{\mathrm{b}} \pm 0.02$ & $2.19^{\mathrm{b}} \pm 0.21$ & $2.02^{\mathrm{a}} \pm 0.00$ & $78.94^{\mathrm{b}} \pm 0.20$ \\
\hline B & $14.74^{\mathrm{b}} \pm 0.15$ & $0.71^{\mathrm{a}} \pm 0.02$ & $1.23^{\mathrm{a}} \pm 0.05$ & $2.36^{\mathrm{b}} \pm 0.33$ & $2.30^{\mathrm{c}} \pm 0.01$ & $78.9^{\mathrm{b}} \pm 0.56$ \\
\hline C & $14.75^{\mathrm{b}} \pm 0.05$ & $0.75^{\mathrm{a}} \pm 0.06$ & $1.66^{\mathrm{c}} \pm 0.09$ & $1.52^{\mathrm{a}} \pm 0.10$ & $2.13^{\mathrm{b}} \pm 0.04$ & $79.19^{\mathrm{b}} \pm 0.18$ \\
\hline D & $14.21^{\mathrm{a}} \pm 0.07$ & $1.06^{\mathrm{c}} \pm 0.07$ & $2.9^{\mathrm{d}} \pm 0.04$ & $3.66^{\mathrm{c}} \pm 0.26$ & $2.17^{\mathrm{b}} \pm 0.19$ & $75.91^{\mathrm{a}} \pm 0.38$ \\
\hline E & $16.05^{\mathrm{c}} \pm 0.06$ & $0.90^{\mathrm{b}} \pm 0.05$ & $1.79^{\mathrm{c}} \pm 0.14$ & $2.27^{\mathrm{b}} \pm 0.07$ & $3.44^{\mathrm{d}} \pm 0.43$ & $75.87^{\mathrm{a}} \pm 0.23$ \\
\hline Min. & 14.21 & 0.71 & 1.23 & 1.52 & 2.02 & 75.87 \\
\hline Max. & 16.05 & 1.07 & 2.99 & 3.66 & 3.44 & 79.19 \\
\hline
\end{tabular}

Results show mean \pm standard deviation of triplicate determinations $(n=3)$. a, b, d Means with the same alphabets within the same column are not significantly different from one another at $\mathrm{P}_{\text {value }}=0.05(\mathrm{p}=0.05)$. Letters $\mathrm{A}$ to $\mathrm{E}$ (upper case letters) represent codes for different yellow gari samples collected

Whereas, the results of ash content (0.71-1.07\%) of yellow gari in this study correspond to those reported by [20]; those of white gari were found to be higher.

The crude protein contents of white gari samples varied significantly from $0.57 \%$ (sample I) to $4.46 \%$ (sample $\mathrm{M}$ ). There was no significant difference in the crude protein contents of samples A, B, E, G, H, J and K. In yellow gari samples, protein contents significantly varied from $1.23 \%$ (sample B) to $2.99 \%$ (sample D). Also, no significant difference was recorded between the protein contents of sample $\mathrm{C}$ and $\mathrm{E}$. The crude protein contents recorded for both white and yellow gari samples in this study were generally low (below $5.0 \%$ ) because gari is not a known protein food.

The fat content of white gari significantly ranged from $0.31 \%$ (sample P) to $2.46 \%$ (sample K). However, there were similarities in the fat contents of samples $0(0.32 \%)$ and $\mathrm{P}(0.31 \%)$. The fat content of yellow gari samples varied from $1.52 \%$ (sample C) to $3.66 \%$ (sample D). The fat contents of yellow gari samples was higher than white gari samples because red oil (palm oil) was added in varying proportions to yellow gari during production or processing.

The crude fibre contents of white gari samples varied significantly from $1.51 \%$ (sample D) to $2.72 \%$ (sample J). Nevertheless, similarities exist in the crude fibre contents of many white gari samples as indicated by the results. The crude fibre contents of yellow gari samples varied significantly from $2.02 \%$ (sample A) to $3.44 \%$ (sample E). There was no significant difference between the crude fibre contents of samples C (2.13\%) and D (2.17\%).

Crude fibre content of any gari sample may be linked directly to the maturity level of cassava from which it is being made, when the roots is allowed to overgrow beyond the normal maturity period, they might become spongy in the soil and hence there is increase in the fibre contents when processed into gari. The National Standard Specifications for gari stated that the crude fibre must not exceed $2.00 \%$. With this specification, $62.5 \%$ of total white gari samples had crude fibre contents above the threshold level while $100 \%$ of the total yellow gari collected had their crude fibre contents beyond the threshold level. The crude fibre contents of white gari (1.49-2.72\%) as reported in this study were found to be lower whereas those of yellow gari were higher than earlier reports [20].

The carbohydrates contents of white gari varied from $77.09 \%$ (sample C) to $84.10 \%$ (sample H). However, similarities exist between the carbohydrates content of sample H (84.10\%) and I (83.57\%). In yellow gari, carbohydrates contents ranged from $75.87 \%$ (sample E) to $79.19 \%$ (sample C). Similarities occurred in the carbohydrates contents of samples $\mathrm{A}, \mathrm{B}$ and $\mathrm{C}$ on one hand, and samples D and E on the other hand. Crude protein, fat and carbohydrates contents of any food contribute to the calorie value; hence, gari could be regarded as energy giving food. Carbohydrates contents of white and yellow gari samples were higher than available literature as published by [20].

\subsection{Physicochemical properties of white and yellow gari samples from Akwanga, Nasarawa State, Nigeria}

The physicochemical properties of white gari samples were as presented (Figure 3). The $\mathrm{pH}$ of white gari samples fell within the low acid region but varied significantly from 4.56 units (sample G) to 5.95 units (sample K) (Figure 3 left). Low acidity in white gari samples was further confirmed by the results of total titratable acidity (TTA). The TTA of white 
gari varied significantly from $0.11 \%$ (sample E) to $0.67 \%$ (sample D) (Figure 3 right). There was no statistical difference between the acidity of samples A and C, samples J and P, samples F, L and M, and samples $\mathrm{O}$ and B.

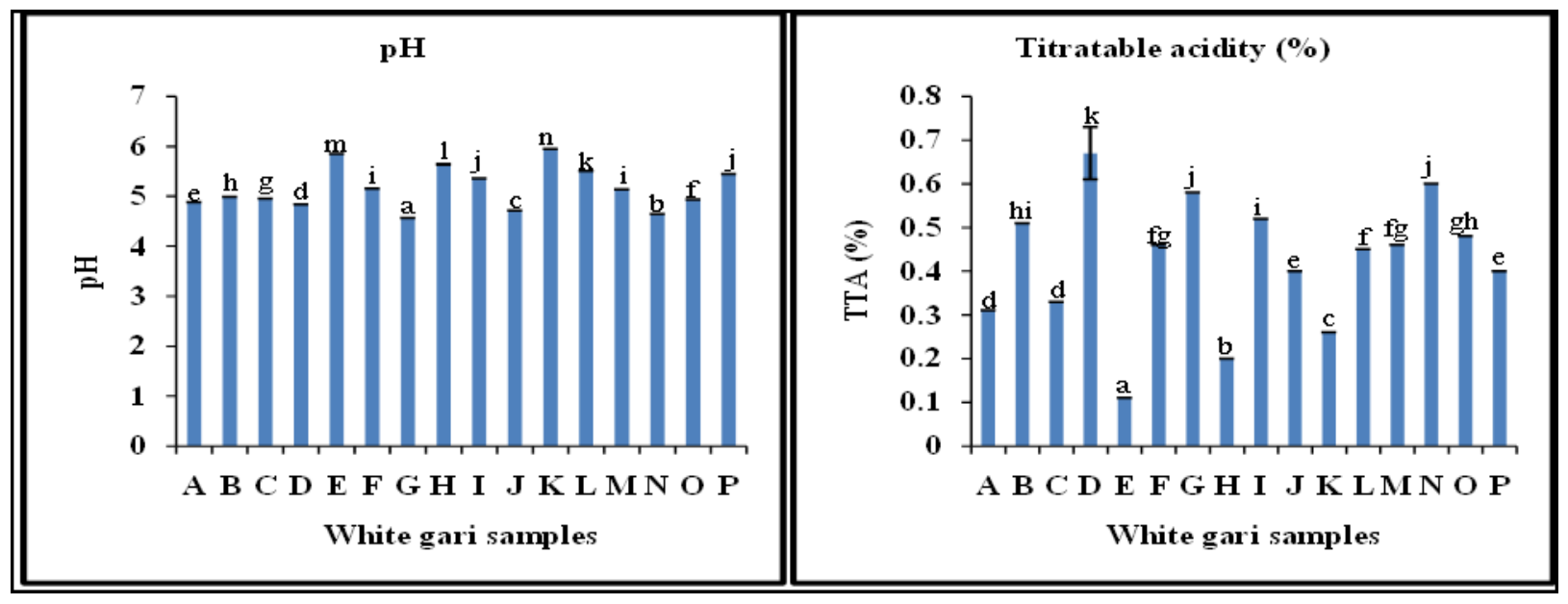

Figure 3 Physicochemical properties (pH and TTA) of white gari from Akwanga, Nasarawa State, Nigeria. Each column bar represents mean of three determinations $(n=3)$ while the error bar represents standard deviation (SD) of the mean. Column bars with unshared alphabets (lower case letters) on top are significantly different at $\mathrm{P}_{\text {value }}=0.05$ $(\mathrm{p}=0.05)$. Letters (upper case) are codes representing white and yellow gari samples respectively

Similarly in yellow gari samples, low $\mathrm{pH}$ was observed. The $\mathrm{pH}$ differed significantly from 4.44 units (sample C) to 5.51 units (sample B) (Figure 4 left). Likewise, the TTA of yellow gari showed low acidity and it varied significantly from $0.11 \%$ (sample B) to $0.60 \%$ (sample A) (Figure 4 right). Meanwhile, there was no significant difference $(\mathrm{p}=0.05$ ) between sample $\mathrm{A}$ and $\mathrm{C}$ in their acidity concentrations ( $0.60 \%$ and $0.57 \%$ respectively).

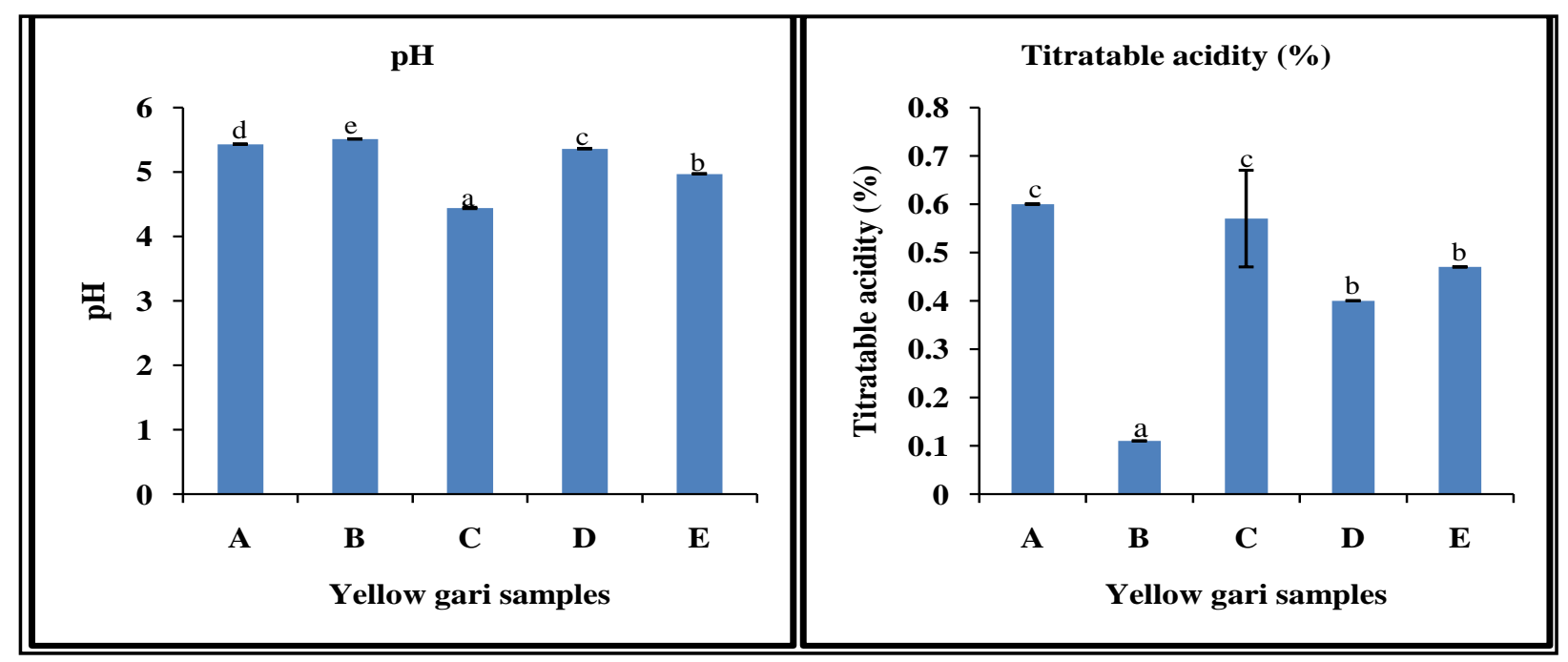

Figure 4 Physicochemical properties ( $\mathrm{pH}$ and TTA) of yellow gari from Akwanga, Nasarawa State, Nigeria. Each column bar represents mean of three determinations $(n=3)$ while the error bar represents standard deviation (SD) of the mean. Column bars with unshared alphabets (lower case letters) on top are significantly different at

$P_{\text {value }}=0.05(p=0.05)$. Letters (upper case) are codes representing white and yellow gari samples respectively.

The results of both $\mathrm{pH}$ and TTA were in agreement with each other in this study. Low acidity corresponds to high $\mathrm{pH}$ values. The acceptable limit for total acidity was set in the range of $0.6-1.0 \%$ according to National Standard Specifications for gari in Nigeria and Codex Alimentarious [7]. The results obtained showed that only three samples (two white and one yellow gari samples) representing $14.29 \%$ of total samples fell within the acceptable limit. Total acidity value could indicate the degree of fermentation in gari. The higher the fermentation process, the higher the total acidity and the better the flavour of gari. 


\subsection{Functional properties of white and yellow gari samples from Akwanga, Nasarawa State, Nigeria}

Functional properties have been defined as those characteristics that govern the behavior of nutrients in food during processing, storage and preparation as they affect food quality and acceptability [15]. They are the fundamental physicochemical properties that reflect the complex interaction between the composition, structure and molecular conformation of food components together with the nature of environment in which they are associated and measured [21]. A functional property of food is determined by physical, chemical and/or organoleptic properties of a food. Typical functional properties examined in the current study include; bulk density (BD), water absorption capacity (WAC) also known as hydration or water binding or capacity, swelling power or swelling index (SI) and least gelation capacity (LGC). The various values obtained for these properties of white gari were as presented in Table 5 . The results showed that bulk density (BD) of white gari samples varied significantly from $0.12 \mathrm{~g} / \mathrm{mL}$ (samples D and E) to $0.87 \mathrm{~g} / \mathrm{mL}$ (sample $0)$. Nevertheless, many white gari samples showed statistical similarities. The BD of yellow gari varied significantly from $0.56 \mathrm{~g} / \mathrm{mL}$ (sample A) to $0.71 \mathrm{~g} / \mathrm{mL}$ (sample C) as shown on Table 6.

Table 5 Functional properties of white gari samples obtained from Akwanga, Nasarawa State, Nigeria.

\begin{tabular}{|c|c|c|c|c|}
\hline Sample & $\begin{array}{l}\text { Bulk Density } \\
(\mathrm{g} / \mathrm{mL})\end{array}$ & $\begin{array}{l}\text { Water Absorption } \\
\text { Capacity }(\mathrm{mL} / \mathrm{g})\end{array}$ & Swelling Power & $\begin{array}{l}\text { Least Gelation } \\
\text { Capacity (\%) }\end{array}$ \\
\hline A & $0.53^{b c} \pm 0.00$ & $4.12^{\mathrm{a}} \pm 0.22$ & $3.27^{\text {cde }} \pm 0.11$ & $5.70^{e} \pm 0.50$ \\
\hline $\mathrm{B}$ & $0.57^{\text {de }} \pm 0.00$ & $5.22^{\mathrm{ef}} \pm 0.12$ & $3.10^{c d} \pm 0.10$ & $5.00^{\mathrm{de}} \pm 0.00$ \\
\hline $\mathrm{C}$ & $0.51^{b} \pm 0.00$ & $4.72^{b c} \pm 0.10$ & $3.30^{\text {de }} \pm 0.20$ & $5.70^{\mathrm{e}} \pm 0.05$ \\
\hline $\mathrm{D}$ & $0.12^{\mathrm{a}} \pm 0.00$ & $4.54^{b} \pm 0.11$ & $3.37^{\mathrm{def}} \pm 0.25$ & $6.70^{f} \pm 0.05$ \\
\hline $\mathrm{E}$ & $0.12^{\mathrm{a}} \pm 0.00$ & $5.30^{f} \pm 0.50$ & $4.00^{\mathrm{h}} \pm 0.00$ & $3.00^{\mathrm{a}} \pm 0.00$ \\
\hline $\mathrm{F}$ & $0.76^{\mathrm{g}} \pm 0.01$ & $4.97^{\text {cde }} \pm 0.01$ & $3.00^{c} \pm 0.20$ & $5.70^{\mathrm{e}} \pm 0.50$ \\
\hline $\mathrm{G}$ & $0.61^{f} \pm 0.00$ & $4.53^{b} \pm 0.17$ & $3.27^{\text {cde }} \pm 0.57$ & $3.70^{\mathrm{ab}} \pm 0.50$ \\
\hline $\mathrm{H}$ & $0.57^{\text {de }} \pm 0.01$ & $4.51^{b} \pm 0.19$ & $3.00^{c} \pm 0.17$ & $4.70^{c d} \pm 0.50$ \\
\hline I & $0.55^{c d} \pm 0.00$ & $4.06^{\mathrm{a}} \pm 0.28$ & $3.40^{\mathrm{ef}} \pm 0.17$ & $5.00^{\mathrm{de}} \pm 0.00$ \\
\hline $\mathrm{J}$ & $0.53^{b c} \pm 0.00$ & $5.14 \mathrm{def} \pm 1.55$ & $2.56^{\mathrm{b}} \pm 0.05$ & $5.00^{\mathrm{de}} \pm 0.00$ \\
\hline $\mathrm{K}$ & $0.86^{h} \pm 0.01$ & $4.92^{\mathrm{cd}} \pm 0.08$ & $3.73^{\mathrm{g}} \pm 0.20$ & $4.70^{c d} \pm 0.50$ \\
\hline $\mathrm{L}$ & $0.59^{\mathrm{e}} \pm 0.00$ & $4.26^{\mathrm{a}} \pm 0.11$ & $3.63^{\mathrm{fg}} \pm 0.25$ & $4.00^{\mathrm{bc}} \pm 0.00$ \\
\hline M & $0.56^{d} \pm 0.01$ & $4.18^{\mathrm{a}} \pm 0.00$ & $0.47^{a} \pm 0.05$ & $4.70^{c d} \pm 0.50$ \\
\hline $\mathrm{N}$ & $0.64^{\mathrm{f}} \pm 0.01$ & $5.11^{\mathrm{def}} \pm 0.00$ & $3.17^{\text {cde }} \pm 0.15$ & $5.00^{\mathrm{de}} \pm 0.00$ \\
\hline 0 & $0.87^{h} \pm 0.02$ & $4.08^{a} \pm 0.18$ & $3.60^{\mathrm{fg}} \pm 0.00$ & $4.70^{c d} \pm 0.50$ \\
\hline $\mathrm{P}$ & $0.52^{b} \pm 0.00$ & $4.73^{b c} \pm 0.20$ & $3.10^{\mathrm{cd}} \pm 0.00$ & $5.00^{\text {de }} \pm 0.00$ \\
\hline Minimum & 0.12 & 4.06 & 0.47 & 3.00 \\
\hline Maximum & 0.87 & 5.30 & 4.00 & 6.70 \\
\hline
\end{tabular}

Results show mean \pm standard deviation of triplicate determinations $(n=3) .{ }^{a, b}, \mathrm{c}, \mathrm{d}$ Means with the same alphabets within the same column are not significantly different from one another at $\mathrm{P}_{\text {value }}=0.05(\mathrm{p}=0.05$ ). Letters $\mathrm{A}$ to $\mathrm{E}$ (upper case letters) represent codes for different yellow gari samples collected. 
Table 6 Functional properties of yellow gari obtained from Akwanga, Nasarawa State, Nigeria.

\begin{tabular}{|c|c|c|c|c|}
\hline Sample & $\begin{array}{l}\text { Bulk Density } \\
(\mathrm{g} / \mathrm{mL})\end{array}$ & $\begin{array}{l}\text { Water Absorption } \\
\text { Capacity (mL/g) }\end{array}$ & Swelling Index & $\begin{array}{l}\text { Least Gelation } \\
\text { Capacity (\%) }\end{array}$ \\
\hline A & $0.56^{\mathrm{a}} \pm 0.00$ & $5.11^{b} \pm 0.09$ & $4.37^{c} \pm 0.55$ & $5.70^{c} \pm 0.50$ \\
\hline B & $0.64^{d} \pm 0.01$ & $4.54^{\mathrm{a} \pm 0.21}$ & $4.40^{c} \pm 0.26$ & $4.00^{a} \pm 0.00$ \\
\hline $\mathrm{C}$ & $0.71^{\mathrm{e}} \pm 0.00$ & $4.37 \mathrm{a} \pm 0.18$ & $3.97 \mathrm{~b} \pm 0.15$ & $5.00^{\mathrm{b}} \pm 0.00$ \\
\hline $\mathrm{D}$ & $0.60^{c} \pm 0.00$ & $4.38^{a} \pm 0.07$ & $3.47^{a} \pm 0.30$ & $6.00^{c} \pm 0.00$ \\
\hline $\mathrm{E}$ & $0.58^{\mathrm{b}} \pm 0.00$ & $5.40^{c} \pm 0.05$ & $4.33^{b c} \pm 0.30$ & $3.70^{a} \pm 0.50$ \\
\hline Maximum & 0.56 & 4.37 & 3.47 & 3.07 \\
\hline Minimum & 0.71 & 5.40 & 4.40 & 6.00 \\
\hline
\end{tabular}

Results show mean \pm standard deviation of triplicate determinations $(n=3) ., a, b, c, d$ Means with the same alphabets within the same column are not significantly different from one another at $\mathrm{P}_{\text {value }}=0.05(\mathrm{p}=0.05)$. Letters $\mathrm{A}$ to $\mathrm{E}$ (upper case letters) represent codes for different yellow gari samples collected.

Bulk density is a measure of heaviness of solid food samples which is essential in determining packaging requirements, material handling application in food industry [22]. Water absorption capacity of white gari significantly differed in this study and it ranged from $4.06 \mathrm{~mL} / \mathrm{g}$ (sample I) to $5.30 \mathrm{~mL} / \mathrm{g}$ (sample E). There were statistical similarities in the WAC of white gari samples A, I, L and O, samples C, D, G, H and P. Likewise between samples E, J and N. Yellow gari samples also showed significant WAC ranging from $4.34 \%$ (sample C) to $5.40 \%$ (in sample E). Similarities in WAC of yellow gari occurred between samples B, C and D. Water absorption capacity (WAC) is the ability of flour to absorb water and swell for improved consistency in food and it's desirable in food system to improve yield and, consistency and give body to the food [23]. High water biding ability of flours limits the amount of water available such that during mixing free water can migrate towards water biding sites and thus increase the viscosity of the products [24]. Khalid et al. [25] observed that heat treated flours tends to absorb more water due to gelatinization of carbohydrates and heat dissociation of pectin. The swelling index of white gari samples ranged from 0.47 to 4.00 . Sample M had the least significant swelling index (0.47) while $\mathrm{E}$ had the highest significant swelling index (4.00). The least gelation capacity of white gari varied significantly from 3.00 to $6.7 \%$ while the yellow gari had gelation capacity between $3.07-6.00 \%$.

\section{Conclusion}

At the end of findings in this study, we made the following conclusions on samples of white and yellow gari collected from Akwanga main market in the month of July, 2019; that all gari samples contained residual hydrogen cyanide above the recommended National Standard Specifications for gari. This is unacceptable and needs urgent attentions from relevant institutions of government and individuals. High proportions of gari ( $62.5 \%$ white and $100 \%$ yellow) samples had moisture contents above safe level. This might make the gari samples susceptible to mould growths and depreciation in quality after some time with associated health risks. However, both white and yellow gari contained ash contents within the acceptable limit.

\section{Compliance with ethical standards}

\section{Acknowledgments}

Authors wish to acknowledge the management of Nigerian stored Products Research Institute, Ilorin for the use of her laboratory in this study. We acknowledge the contributions of Mr. Gudi Kreni (Chief Technician) Chemistry Laboratory, Department of Chemistry, College of Education (COE), Akwanga, Nasarawa State, Nigeria for the role he played during collection of samples used in this study.

\section{Disclosure of conflict of interest}

Authors declare no conflict of interest in this study. 


\section{References}

[1] Amadi JE and Adebola MO. (2008). Effect of moisture content and storage conditions on the storability of gari. African Journal of Biotechnology, 7 (24), 4591-4594.

[2] Onyenwoke CA and Simonyan KJ. (2014). Cassava post-harvest processing and storage in Nigeria: A review. African Journal of Agricultural Research, 9(53), 3853-3863.

[3] Onabowale SO. (2015). Contraints and Projections for processing and utilization of cassava. Cassava as livestock feed in Africa-Proceeding of the IITA/ILCA.

[4] Kouakou J, Nanga SN, Plagne-Ismail C, Pali AM and Ognakossan KE. (2016). Cassava Production and Processing. Pro-Agro Collection: A Publication by Engineers without Boarders, Cameroon and Technical Centre for Agricultural and Rural Cooperation (CTA), Netherlands, 3-4.

[5] Taiwo KA and Fasoyiro SB. (2015). Women and Cassava Processing in Nigeria. International Journal of Development Research, 5(2), 3513-3517.

[6] Cassava Master Plan (2006). A strategic action plan for the development of Nigerian cassava industry. Prepared within the framework of the Nigeria country service framework and in cooperation with the presidential initiative on cassava in collaborations with UNIDO, 8-12.

[7] Oti E, Onadipe O, Sebastienne D, Egounlety M, Detouc N, Gregory AK and Loueke GM. (2010). Training manual on processing of cassava into gari and high quality cassava in West Africa. USAD/CORAF/SONGHAI, 8-28.

[8] James B, Okechukwu R, Abass A, Fannah S, Maziya-Dixon B, Sanni L, Osei-Sarfoh A, Fomba S and Lukombo S. (2012). Producing Gari from Cassava: An illustrated guide for smallholder cassava processors. International Institute of Tropical Agriculture (IITA): Ibadan, Nigeria, 1-5.

[9] Emoyan 00, Agbaire PO and Peretieo-Clarke BO. (2012). Determination of Residual Hydrocyanic Acid (HCN) in White and Yellow Garri Flour Processed from Cassava (Manihot esculata Crantz). Research Journal of Chemical Sciences, 2(12), 78-80.

[10] Anhwange BA, Asemave K, Ikyenge BA and Oklo DA. (2011). Hydrogen Cyanide Content of Manihort utilissima, Colocasia esculenta, Dioscorea bulbifera and Dioscorea domentorum Tubers Found in Benue State. International Journal of Chemistry, 3(4), 22-30.

[11] Etonihu AC, Olajubu 0, Ekanem EO and Bako SS. (2011). Titrimetric Evaluation of Cyanogens in Parts of Some Nigerian Cassava Species. Pakistan Journal of Nutrition, 10(3), 260-263.

[12] Ojo RT, Obi NP, Akintayo CO and Adebayo-Gege GI. (2013). Evaluation of Cyanogen contents of cassava and cassava based food products in Karu, Nasarawa State, North-Central Nigeria. IOSR Journal Environmental Science, Toxicology and Food Technology, 6(1), 47-50.

[13] Orjiekwe CL, Solola A, Iyen E and Imade S. (2013). Determination of Cyanogenic glycosides in Cassava products sold in Okada, Edo State, Nigeria. African Journal of Food Science, 7(12), 468-472.

[14] Akande SA, Onyegbula AF, Salawu RA, Oladipo AK and Adetunji CO. (2017). Effects of post-harvest handling on hydrogen cyanide content of cassava products obtained from Ilorin-West urban markets, Nigeria African Journal of Food Science, 11(11), 362 - 369.

[15] Onwuka GI. (2005). Food Analysis and Instrumentation. Theory and Practice. Naphtali Prints, Lagos, Nigeria, 122128.

[16] AOAC (2000). Official Methods of Analysis of Association of Official Analytical Chemists International 17th Ed. AOAC International Suite 500481 North Frederick Avenue. Gaithersburg, Maryland, 20877-2417.

[17] Onwuka GI and Ogbogu NJ. (2007). Effect of fermentation on the quality and physicochemical properties of cassava based fufu products made from two cassava varieties NR8212 and Nwangbisi. Journal of Food Technology, 5(3), 261-264.

[18] Abbey BW and Ibeh GO. (1988). Functional properties of raw and heat processed cowpea flour. Journal of Food Sciences, 53, 1775-1791.

[19] Duncan PB. (1955). New Multiple Range and Multiple F-tests. Biometrics 11:1-42. 
[20] Adetunji CO, Akande SA, Oladipo AK, Salawu RA and Onyegbula AF. (2017). Determination of the microbiological quality and proximate composition of fermented cassava food products sold in Ilorin-west local government area, Nigeria. Ruhuna Journal of Science, 8, $76-89$.

[21] Suresh Chandra and Samsher (2013). Assessment of functional properties of different flours. African Journal of Agricultural research, 8(38), 4849-4852.

[22] Falade KO and Okafor CA. (2015). Physical, functional, and pasting properties of flours from corms of two Cocoyam (Colocasia esculenta and Xanthosoma sagittifolium) cultivars. Journal of Food Science and Technology, $52(6), 3440-3448$.

[23] Offia-Olua BI. (2014). Chemical, functional and pasting properties of wheat (Triticum spp.)-Walnut (Juglanregia) flour. Food and Nutrition Sciences, 5, 1591-1604.

[24] Ajani AO, Fasoyiro SB, Arowora KA, Ajani O0, Popoola CA and Zaka KO. (2016). Functional Properties of Composite Flour made from Wheat and Breadfruit. Applied Tropical Agriculture, 21(2), 89-93.

[25] Khalid EK, Babiker EE and Tinay AH. (2003). Solubility and functional properties of sesame seed proteins as influenced by $\mathrm{pH}$ and/or salt concentration. Food Chemistry, 82, 361-366.

\section{How to cite this article}

Kreni CG, Akande SA, Ayanda IS and Ibrahim AS. (2019). Quantitative evaluation of hydrogen cyanide content, chemical and functional properties of gari from Akwanga, Nasarawa State, Nigeria. World Journal of Advanced Research and Reviews, 4(1), 13-24. 